\title{
Myxobolus cerebralis infection patterns in Yellowstone cutthroat trout after natural exposure
}

\author{
Silvia Murciaa ${ }^{1, *}$, Billie L. Kerans ${ }^{1}$, Elizabeth MacConnell ${ }^{2}$, Todd M. Koel ${ }^{3}$ \\ ${ }^{1}$ Department of Ecology, 310 Lewis Hall, Montana State University, Bozeman, Montana 59717, USA \\ ${ }^{2}$ Fish and Wildlife Service, Bozeman Fish Health Center, 920 Technology Blvd S, Bozeman, Montana 59715, USA \\ ${ }^{3}$ Center for Resources, Fisheries and Aquatic Sciences Section, PO Box 168 Yellowstone National Park, Wyoming 82190, USA
}

\begin{abstract}
Salmonid species and sub-species exhibit a range of susceptibility to Myxobolus cerebralis infection. Little is known about lesion severity and location, or time required for $M$. cerebralis myxospores to develop in Yellowstone cutthroat trout Oncorhynchus clarki bouvieri. In 2002 we performed three $10 \mathrm{~d}$ exposures of Yellowstone cutthroat trout fry in Pelican Creek, an M. cerebralispositive tributary to Yellowstone Lake. At 90 and $150 \mathrm{~d}$ post-exposure we examined the fish for clinical signs, for infection prevalence, and by histology to determine $M$. cerebralis infection location and severity of lesions. The most prevalent clinical signs in Yellowstone cutthroat were whirling behavior and skeletal deformities, especially at $90 \mathrm{~d}$ post-exposure. Prevalence of infection and severity of cartilage lesions were not statistically different between fish held for 90 or $150 \mathrm{~d}$ post-exposure. Histopathology was most severe in cartilage of the cranium and the lower jaw, whereas cartilage of the nares and gill arches was seldom damaged. This study suggests that Yellowstone cutthroat trout are highly vulnerable to $M$. cerebralis and that current population declines in the Yellowstone Lake basin may, in part, result from whirling disease. Our results answer important questions in fish health and will aid in the development of diagnostic tools and management efforts against this pathogen in native cutthroat trout and other vulnerable salmonids.
\end{abstract}

KEY WORDS: Myxobolus cerebralis · Lesion location - Lesion severity · Yellowstone cutthroat trout · Whirling disease

Resale or republication not permitted without written consent of the publisher

\section{INTRODUCTION}

The long-term survival of the Yellowstone cutthroat trout Oncorhynchus clarki bouvieri is of significant conservation concern among fishery biologists and managers across the Intermountain West of North America. Yellowstone Lake, located within Yellowstone National Park, has one of the largest remaining populations of Yellowstone cutthroat trout; however, recent invasion by non-native lake trout Salvelinus namaycush (Ruzycki et al. 2003, Koel et al. 2005) threatens this population, as potentially does the recently introduced New Zealand mud snail Potamopyrgus antipodarum (Kerans et al. 2005). The parasite causing whirling disease in salmonids, Myxobolus cerebralis, was first detected in Yellowstone Lake in 1998 and has since posed an additional threat to the status of the Yellowstone cutthroat trout population there (Koel et al. in press). Information is needed on the susceptibility and pathology (e.g. location of lesions, clinical signs) in wild fish to guide future diagnostic and management efforts.

Salmonid species and sub-species exhibit a range of susceptibility to infection by Myxobolus cerebralis (O'Grodnick 1979, Hedrick et al. 1999a, MacConnell \& Vincent 2002), and of the species studied to date, rainbow trout Oncorhynchus mykiss are the most susceptible (Halliday 1976, O'Grodnick 1979, Hoffman 1990, Markiw 1992, Hedrick et al. 1999a,b, Vincent 2002). Cutthroat trout coexist with rainbow trout in many watersheds of the Intermountain West and are also vulnerable to the parasite (Hedrick et al. 1998, Wagner et al. 2002). However, susceptibility of different cutthroat trout sub-species, including Yellowstone cut- 
throat, remains a subject of debate (e.g. Hedrick et al. 1999a, Thompson et al. 1999, Hiner \& Moffitt 2001, MacConnell \& Vincent 2002, Vincent 2002, Wagner et al. 2002).

The location of cartilage lesions caused by the presporogonic stages of Myxobolus cerebralis differs among various salmonids (Hedrick 1999a, Vincent 2002). The parasite causes microscopic lesions in cartilage of the fin rays and gill arches of brown trout Salmo trutta when exposed to high parasite doses, but in rainbow trout, lesions are most common in cartilage of the cranium (Hedrick et al. 1999b, Baldwin et al. 2000, MacConnell \& Vincent 2002). The regions of cartilage most severely damaged by the parasite have not been examined in Yellowstone cutthroat trout, although some studies have examined the degree of microscopic pathology and prevalence of clinical signs (Hedrick et al. 1999a, Hiner \& Moffitt 2001, Vincent 2002).

To determine microscopic pathology, histological examination is typically conducted at $90 \mathrm{~d}$ post-exposure when maximum cartilage inflammation and complete myxospores can be detected in rainbow trout (Halliday 1976, Markiw 1992, Vincent 2002).

However, some research suggests that infected fish should be examined $150 \mathrm{~d}$ postexposure (e.g. Ryce et al. 2005). Lesion severity in Yellowstone cutthroat trout has been examined 90, 123, and $150 \mathrm{~d}$ post-exposure (Hedrick et al. 1999a, Vincent 2002), but it remains unclear when peak infection severity can be most effectively detected in Yellowstone cutthroat trout.

To address these uncertainties, we examined Yellowstone cutthroat fry exposed at 3 different times in a Myxobolus cerebralis-positive tributary of Yellowstone Lake (Koel et al. in press) at 90 and 150 d post-exposure. Our objectives were to determine whether (1) the prevalence of clinical signs, (2) the prevalence of infection, (3) the severity of cartilage lesions in sections taken from medial and lateral cuts of each fry head, and (4) the location of microscopic lesions within the head all differed between 2 post-exposure periods and among exposure times.

\section{MATERIALS AND METHODS}

Study area and field exposures. Pelican Creek is the second largest tributary to Yellowstone Lake, Yellowstone National Park, Wyoming, USA (Fig. 1). Most of Pelican Creek (2400 m above sea level) is low gradient, meandering through sub-alpine meadows
(Parks 1998). Pelican Creek is highly infected by Myxobolus cerebralis (Koel et al. in press).

We obtained parasite-free Yellowstone cutthroat fry (4 to 6 wk old) for use in field exposures from wild Yellowstone River or Clear Creek brood-stocks that are collected annually by the Wyoming Game and Fish Department's Hatchery programs. Field exposures were conducted by placing fish in sentinel cages along the stream bank at 4 sites in the lower $14 \mathrm{~km}$ of Pelican Creek. The sentinel cages were screened, cylindrical enclosures about $1 \mathrm{~m}$ in height and $50 \mathrm{~cm}$ in diameter. Cages were replicated (2 cages, 50 to $60 \mathrm{~m}$ apart) at all but one site. Sixty fry were exposed in each cage for $10 \mathrm{~d}$ in July (10th to 20th), August (7th to 17th), and September (August 28th to September 7th) 2002 ( 7 cages $\times 3$ exposures $=21$ cages used in total). Two cages were lost during the July exposure and fish had to be re-exposed between July 19 and 29. During each exposure, a control group of 60 Yellowstone cutthroat fry were held in the National Park Service Lake Aquatic Resources Laboratory on well water for $10 \mathrm{~d}$ and fed a standard commercial trout feed. At the end of

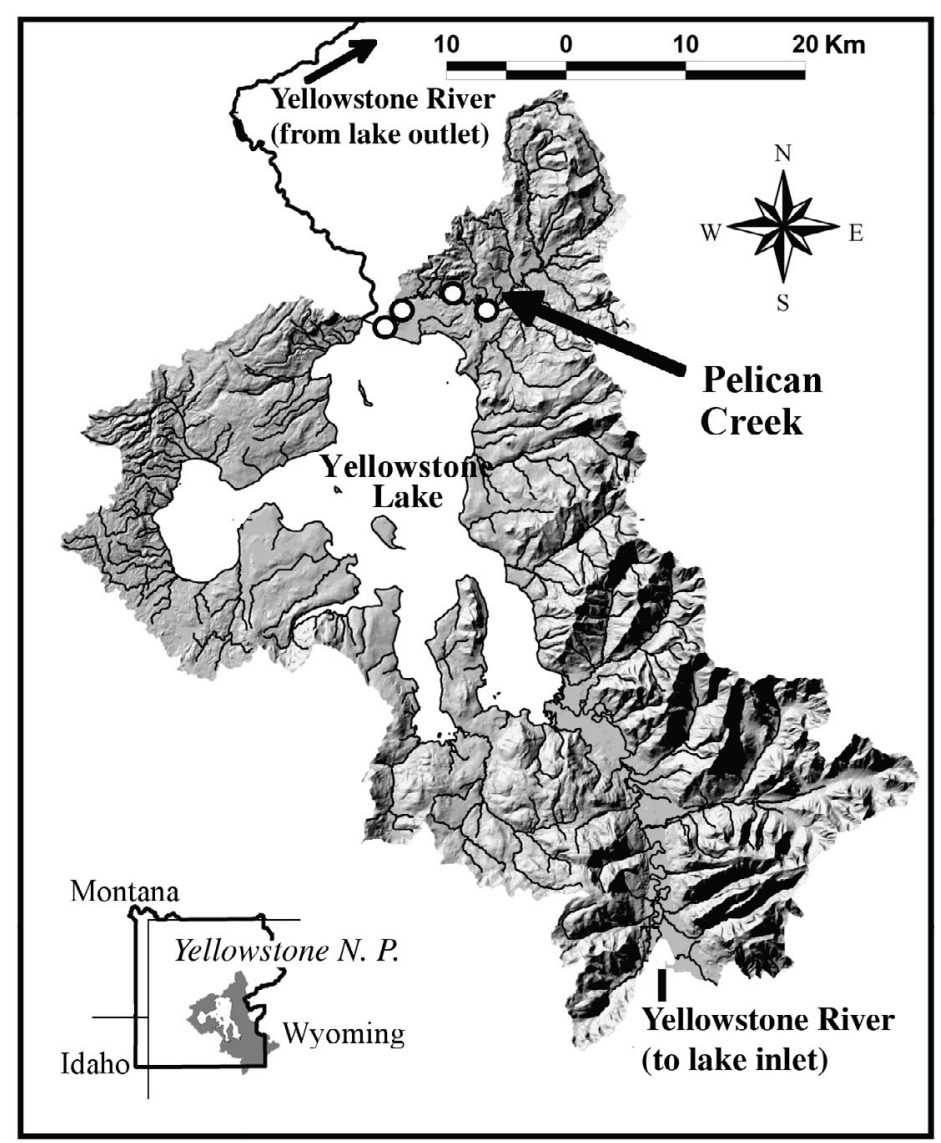

Fig. 1. Yellowstone area. (O) Study sites in Pelican Creek, where replicate sentinel cages were deployed 3 times during the summer (JulySeptember) of 2002 (image adapted from Koel et al. in press) 
each exposure, fry were transported to the Wild Trout Research Laboratory (WTRL), Montana State University, Bozeman, and held in separate aquaria at 12 to $13^{\circ} \mathrm{C}$ for either 90 or $150 \mathrm{~d}$.

Water temperature was recorded hourly at each sentinel site using an Optic Stowaway Temperature Logger (Onset Computer Corporation). At each site during each exposure, we measured specific conductivity and dissolved oxygen concentration using a YSI 85 multiparameter meter (Yellow Springs Instruments), and $\mathrm{pH}$ using an Oakton Instruments $\mathrm{pH}$ Tester.

Clinical signs and infection prevalence. From each aquarium, random samples of 10 fish were collected on Day 90 post-exposure and up to 20 fish on Day 150 post-exposure. Fry were observed for 30 to $60 \mathrm{~s}$ for clinical signs of whirling disease (whirling, black tail, skeletal deformities) prior to being sacrificed in tricaine methane-sulfonate (MS-222). Heads were removed just behind the opercula and bisected along the sagittal line. One half was immediately preserved in Davidson's fixative (Humason 1979) for later histological examination and the corresponding half-head frozen at $-70^{\circ} \mathrm{C}$ for DNA analysis. Frozen half heads were tested by nested polymerase chain reaction (PCR) for Myxobolus cerebralis DNA (Andree et al. 1998). From each head we took a $5 \mathrm{~mm}$ cranial biopsy punch and pooled 5 punches in a $1.5 \mathrm{ml}$ microcentrifuge tube with $180 \mu \mathrm{l}$ of Qiagen-ATL lysis buffer (Qiagen Dneasy tissue kit \# 69506).

Histology. Half-heads previously preserved in Davidson's fixative whose corresponding half-head tested positive for Myxobolus cerebralis DNA by PCR were processed for microscopic examination using standard histological techniques (Humason 1979). Two $5 \mu \mathrm{m}$-thick tissue sections 150 to $200 \mu \mathrm{m}$ apart (a medial section near the brain, and a lateral section near the skin) from each half head were stained with hematoxylin and eosin, and examined for location and severity of lesions. In addition, a random sub-sample of 30 PCR-negative half heads was examined to verify lack of infection. Tissue sections were evaluated without the investigators having knowledge of sentinel cage site or PCR results. Microscopic lesions for 6 areas of head cartilage (nares, gill arches, lower jaw, upper jaw, vertebra, and cranium) were scored on a scale of zero (no infection) to 5 (severe infection) (Table 1) (Andree et al. 2002, Ryce et al. 2005).

Statistical analyses. The non-parametric chi-square test of homogeneity was used to determine whether the frequency of clinical signs and the prevalence of infection differed between post-exposure periods (90 or $150 \mathrm{~d}$ ) within each $10 \mathrm{~d}$ exposure (July, August, September) and among each $10 \mathrm{~d}$ exposure within each post-exposure period. Lesion severity scores for all areas of the head cartilage and inflammation were compared between post-exposure periods within medial and lateral sections and between sections within each post-exposure period using the same test. We pooled data from the three $10 \mathrm{~d}$ exposures for lesion severity tests because we had insufficient data to examine them separately and our interest was in the patterns of pathology.

When expected chi-square values were $<1$, we either combined cells to achieve expected values $>1$ or we used the continuity correction for small sample sizes (Gotelli \& Ellison 2004). All statistical analyses were carried out with the statistical software program SAS 9.0 (SAS Institute 2004) and $\alpha$-value 0.05 as the critical value in all tests of significance.

Table 1. Myxobolus cerebralis. Cartilage lesion severity ratings used in this study. Adapted from MacConnell-Baldwin scale for scoring lesions (Andree et al. 2002)

\begin{tabular}{|c|c|c|}
\hline $\begin{array}{l}\text { Numerical } \\
\text { score }\end{array}$ & Category & Description \\
\hline 0 & No infection & $\begin{array}{l}\text { No abnormalities noted, } M \text {. cerebralis } \\
\text { not present. }\end{array}$ \\
\hline 1 & Minimal & $\begin{array}{l}\text { Small, discrete foci of cartilage } \\
\text { degeneration, no inflammatory cells. }\end{array}$ \\
\hline 2 & Mild & $\begin{array}{l}\text { One locally extensive focus or several } \\
\text { smaller foci of cartilage degeneration No } \\
\text { or minimal (inflammatory) host response } \\
\text { causing no bone distortion or involvement } \\
\text { of surrounding tissues, very localized } \\
\text { response. }\end{array}$ \\
\hline 3 & Moderate & $\begin{array}{l}\text { Several foci of cartilage infected, cartilage } \\
\text { degeneration and necrosis, inflammatory } \\
\text { response has minimal or mild impact on } \\
\text { surrounding tissues. }\end{array}$ \\
\hline 4 & Moderate-severe & $\begin{array}{l}\text { Several to coalescing areas of cartilage } \\
\text { degeneration and necrosis, locally } \\
\text { extensive areas of granulomatous inflam- } \\
\text { mation, and moderate to severe involve- } \\
\text { ment of surrounding tissues. }\end{array}$ \\
\hline 5 & Severe & $\begin{array}{l}\text { All areas of cartilage examined in the } \\
\text { region are infected. Granulomatous } \\
\text { inflammation is extensive with severe } \\
\text { impact on surrounding tissues. This } \\
\text { rating characterized by loss of normal } \\
\text { architecture, such as bone displaced into } \\
\text { the brain or spinal cord. }\end{array}$ \\
\hline
\end{tabular}




\section{RESULTS}

Mean water temperature was highest during the July exposure, specific conductivity was highest during the September exposure, and dissolved oxygen and $\mathrm{pH}$ were highest during the August exposure (Table 2). Fish mortality in the field was $44 \%$ during the July exposure, $13.5 \%$ during the August exposure, and $16 \%$ during the September exposure. Laboratory mortality prior to the 90 -d sampling was $12 \%, 12 \%$, and $5 \%$ for the July, August, and September exposures, respectively. Laboratory mortality between Days 90 and 150 was $5 \%, 2 \%$, and $5 \%$, for the July, August, and September exposures, respectively.

\section{Clinical signs and infection prevalence}

Across all 3 exposures, whirling behavior was the most frequent sign of disease, occurring at an average rate of $30 \%$ of the fish at $90 \mathrm{~d}$ post-exposure (38/127; number of fry whirling divided by the total number examined, all ratios below are reported in a similar manner) and $16 \%(32 / 205)$ at $150 \mathrm{~d}$ post-exposure. The frequency of whirling did not differ between fish held for 90 or $150 \mathrm{~d}$ post-exposure after the July and August exposures $\left(\chi^{2}{ }_{1}<1.52, \mathrm{p}>0.2280\right.$ for both tests) (Fig. 2). After the September exposure, however, whirling was more frequent in fish held for $90 \mathrm{~d}$ than in fish held for $150 \mathrm{~d}\left(\chi^{2}{ }_{1}=17.39, \mathrm{p}<0.0001\right)$ (Fig. 2). Within the $90 \mathrm{~d}$ post-exposure period, frequency of whirling was lower after the August than after the July or September exposures $\left(\chi^{2}{ }_{2}=16.42, p=0.0003\right)$ (Fig. 2). Within the $150 \mathrm{~d}$ post-exposure period, frequency of whirling was lower after the September than after the July or August exposures $\left(\chi_{2}^{2}=13.26, p=0.0013\right)$ (Fig. 2).

Across all 3 exposures, $8 \%(10 / 127)$ and $2 \%(5 / 205)$ of the fish exhibited skeletal deformities when examined at 90 and $150 \mathrm{~d}$ post-exposure, respectively. The frequency of skeletal deformities was higher in fish held for $90 \mathrm{~d}$ post-exposure than in fish held $150 \mathrm{~d}$ post-exposure after the July $(9 \%, 4 / 47 ; 0 \%, 0 / 65$; respectively) and September exposures $(15 \%, 6 / 40$;

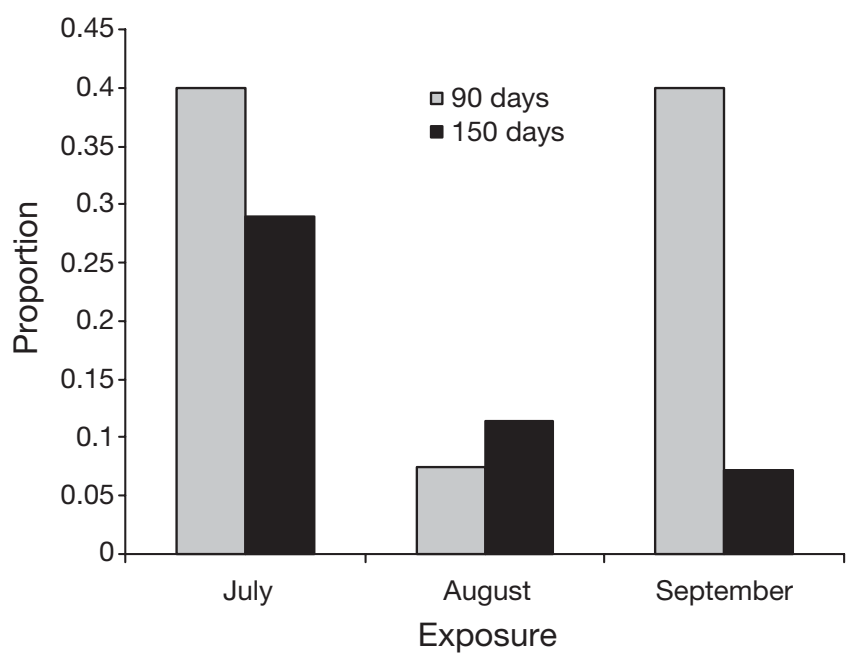

Fig. 2. Proportion of sentinel Yellowstone cutthroat exhibiting whirling behavior 90 and $150 \mathrm{~d}$ post-exposure for the 3 exposures (July, August, September). Results shown were combined across study sites (see Fig. 1)

$0 \%, 0 / 70$ fish; respectively) $\left(\chi^{2}{ }_{1}>7.15, \mathrm{p}<0.0075\right.$ for both tests). However, after the August exposure, skeletal deformities were less frequent in fish held for $90 \mathrm{~d}$ $(0 \%, 0 / 40)$ than in those held for $150 \mathrm{~d}$ post-exposure $(7 \%, 5 / 70)\left(\chi^{2}{ }_{1}=4.66, p=0.0310\right)$. Within the $90 \mathrm{~d}$ postexposure period, skeletal deformities were less frequent after the August exposure (0/40) than after the July $(9 \%, 4 / 47)$ or September exposures $(15 \%, 6 / 40)$ $\left(\chi_{2}^{2}=8.85, \mathrm{p}=0.012\right)$. Within the $150 \mathrm{~d}$ post-exposure period, skeletal deformities were more frequent after the August $(7 \%, 5 / 70)$ than after the July $(0 \%, 0 / 65)$ or September $(0 \%, 0 / 70)$ exposures $\left(\chi^{2}{ }_{2}=10.99, \mathrm{p}=\right.$ 0.0041).

Black tails were seldom observed. Only $6 \%(8 / 127)$ of fish exhibited black tails on Day 90 post-exposure and this occurred only after the July exposure. No fish exhibited black tails 150 d post-exposure $(\mathrm{n}=205)$. Thus, we did no statistical tests on prevalence of black tails.

Across all 3 exposures, the prevalence of infection was $68 \%$ in fish held for $90 \mathrm{~d}$ (17/25 5-fish samples) or 150 d (29/42 5-fish samples) post-exposure. We detected no difference in prevalence of infection between fish held for 90 or $150 \mathrm{~d}$ post exposure after the July $(78 \%, 7 / 9$ and $79 \%, 11 / 14$, respectively), August $(38 \%, 3 / 8$ and $29 \%$, $4 / 14$, respectively) and September $(88 \%, 7 / 8$ and $100 \%, 14 / 14$ fish, respectively) exposures (all 3 values of $\left.\chi^{2}{ }_{1}<2.11, p>0.1466\right)$. The prevalence of infection was lower after the August $(29 \%, 4 / 14$ fish) than after the July $(79 \%, 11 / 14)$ or September 
(100\%, 14/14 fish) exposures in fish held for $150 \mathrm{~d}$ post-exposure $\left(\chi^{2}{ }_{2}=20.67, \mathrm{p}<0.0001\right)$. The same pattern occurred within the $90 \mathrm{~d}$ post-exposure period (July, 78\%, 7/9 fish; August, 38\%, 3/8 fish; September, $88 \%, 7 / 8$ fish), but this was a marginally significant difference $\left(\chi_{2}^{2}=5.20, \mathrm{p}=0.0744\right)$.

\section{Microscopic pathology}

Infection was most frequent in cartilage of the cranium, lower jaw, and to a lesser degree, cartilage of the upper jaw (Fig. 3). Cartilage of the nares and gill arches were seldom affected. Lesions were only
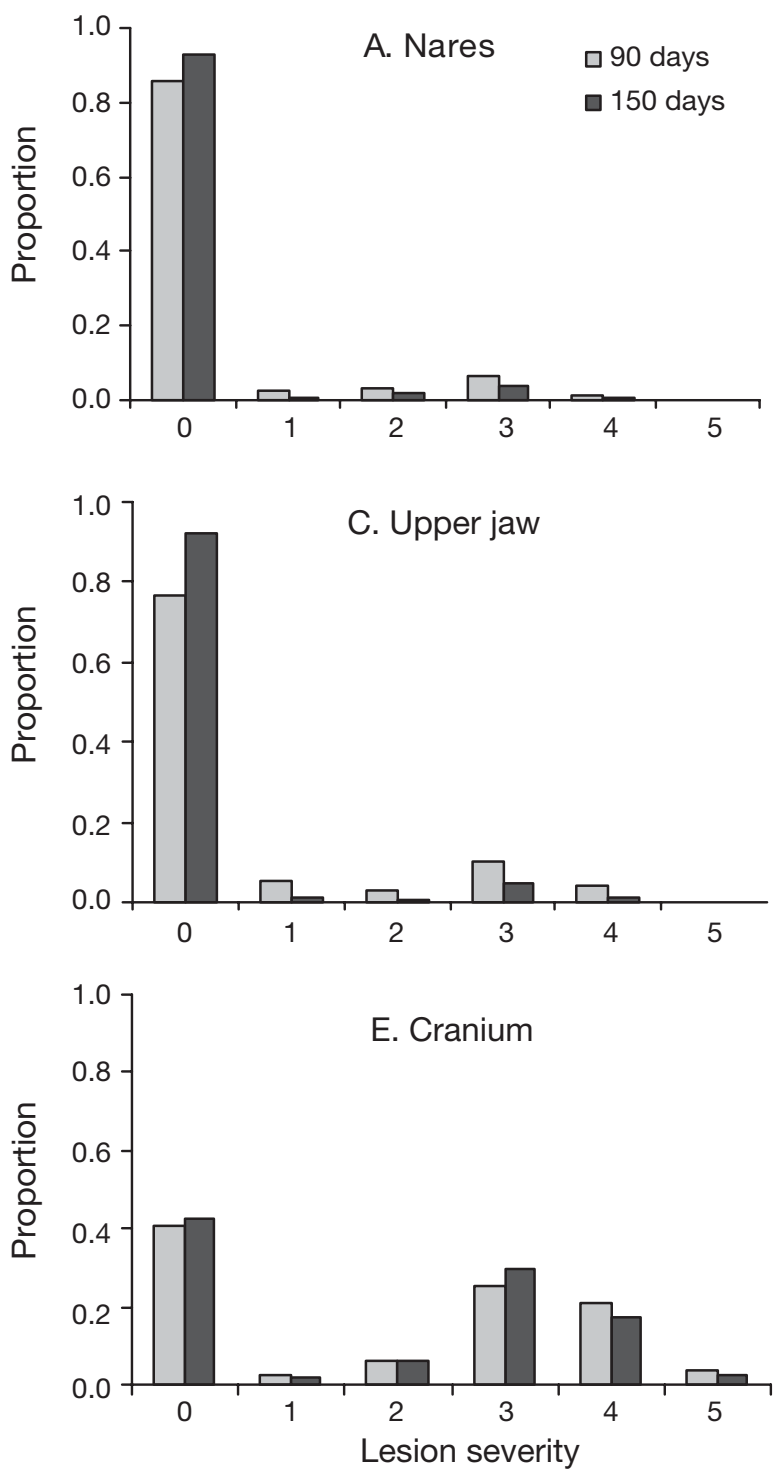

observed twice in the vertebra and thus were not statistically analyzed (and not shown in Fig. 3). We detected no differences in lesion severity scores in all regions of cartilage and overall inflammation between section depths in fish held for 90 or $150 \mathrm{~d}$ post-exposure (all $\mathrm{p}>0.0881$ ). Within section depth, the frequency of fish with microscopic lesions in the upper jaw was higher in fish held for 90 than $150 \mathrm{~d}$ in both the medial $\left(\chi_{4}^{2}=10.873, \mathrm{p}=0.0280\right)$ and lateral sections $\left(\chi^{2}{ }_{4}=17.432, p=0.0016\right)$ (Fig. 3 C). Severity of microscopic lesions did not differ between fish held for 90 or $150 \mathrm{~d}$ for all other regions of cartilage examined and for overall inflammation in both section depths (all p > 0.1582) (Fig. 3).
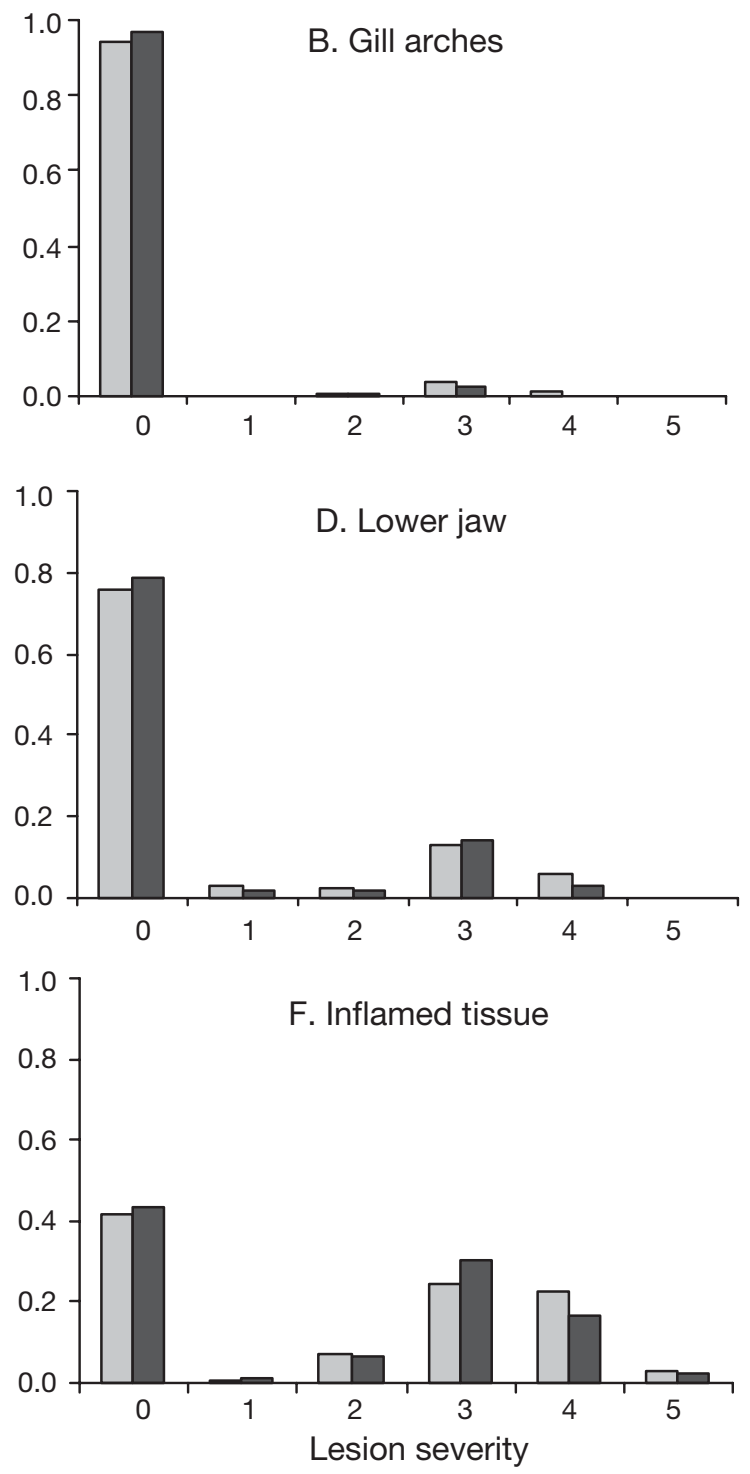

Fig. 3. Myxobolus cerebralis. Severity and location of microscopic pathology in PCR-positive Yellowstone cutthroat fry; (A to E) 5 regions of head cartilage and (F) inflamed tissue were histologically examined and individually rated 90 and $150 \mathrm{~d}$ postexposure (lesion severity categories described in Table 1). Results were combined for all 3 exposures, study sites, and histological section depths 


\section{DISCUSSION}

Whirling disease may be a significant stressor to an already declining population of Yellowstone cutthroat trout in Yellowstone Lake. We investigated the susceptibility of Yellowstone cutthroat trout to whirling disease and demonstrated that (1) they can be highly infected, especially in cartilage of the cranium and lower jaw; (2) it is sufficient to examine them $90 \mathrm{~d}$ postexposure to determine prevalence and severity of infection; and (3) lesion severity was similar between medial and lateral head sections.

Based on our results of infection prevalence (clinical signs and PCR) and disease severity (histology) in Yellowstone cutthroat trout, especially in the cranium, this salmonid's susceptibility to Myxobolus cerebralis infection may be high. Because damage in this area can significantly compromise long-term survival (Vincent 2002) our findings suggest that population level declines of infected Yellowstone cutthroat trout are likely. Damage to jaw cartilage and consequent deformities can hinder the fish's ability to feed normally (El-Matbouli et al. 1992, MacConnell \& Vincent 2002) and further compromise survival in the wild. No prior studies have examined location of lesions in subspecies of cutthroat trout, information which is important in order to assess the risk of whirling disease among native trout populations.

Prompt detection and management of whirling disease in the wild are critical for the long-term survival of the Yellowstone cutthroat trout. We suggest that prevalence and severity of infection in native cutthroat trout be examined $90 \mathrm{~d}$ after parasite exposure. Our results on infection prevalence and disease severity showed no significant difference between 90 and $150 \mathrm{~d}$ post-exposure. Likewise, whirling behavior was not significantly different between 90 and 150 d postexposure, except in September when whirling was more prevalent at 90 than at $150 \mathrm{~d}$ after exposure. Skeletal deformities were also more prevalent 90 than 150 d post-exposure, except in August. Hence, it would be unnecessary to hold and maintain Yellowstone cutthroat trout in live aquaria for longer than $90 \mathrm{~d}$ after parasite exposure.

Although histological examination of Yellowstone cutthroat fry heads at 2 different tissue depths showed no statistical difference in severity of microscopic pathology, this could have resulted if our sections were not far enough apart. When we examined sections 500 to $600 \mu \mathrm{m}$ apart, some fry with no apparent infection showed moderate to high infections in the second (deeper) section (S. Murcia unpubl. data). Therefore, we recommend additional testing for such infection differences by histologically examining fish heads at more than one depth, preferably with sections
$>500 \mu \mathrm{m}$ apart, or more for larger heads. Fry over 6 or 7 wk of age may be large enough that histological analyses at a single cross-section of the head, $5 \mu \mathrm{m}$ in thickness, may provide incomplete and inaccurate information on infection patterns. Fish heads are complex, 3-dimensional structures where Myxobolus cerebralis is likely to reside in variable amounts across given tissues, within different sizes or species of fish.

Susceptibility to Myxobolus cerebralis varies among different species and sub-species of salmonids (O'Grodnick 1979, Hedrick et al. 1999a,b, MacConnell \& Vincent 2002), and manifestation of disease differs as well. Whirling behavior was the most frequent clinical sign we observed in Yellowstone cutthroat trout, whereas it was very seldom reported of brown trout (Hedrick et al. 1999b), and rainbow trout (Ryce et al. 2004). We observed marked skeletal deformities of the head (especially at the jaw) in $8 \%$ of sentinel Yellowstone cutthroat fry $90 \mathrm{~d}$ post-exposure. Black tail was the most prevalent manifestation of whirling disease in brown and rainbow trout (Hedrick et al. 1999b). However, this was the least prevalent manifestation of disease we observed in Yellowstone cutthroat trout, with only a few fry from the July exposure showing black tails $90 \mathrm{~d}$ post-exposure.

These differences in external signs of disease among different trout species may reflect the different internal location of lesions caused by Myxobolus cerebralis in salmonids. When the parasite invades cartilage of the posterior spinal column, increasing pressure on the caudal nerves controlling pigmentation, it causes the darkened caudal regions (or black tails) of infected salmonids (Halliday 1976, Hedrick et al. 1999b, MacConnell \& Vincent 2002). However, cartilage lesions and consequent inflammation restricting the lower brain stem and spinal cord were proposed causes of whirling behavior among infected trout and salmon (Hedrick et al. 1999b, Rose et al. 2000). The high prevalence and severity of lesions in cranial cartilage and inflammation in Yellowstone cutthroat trout may partially explain why whirling was a frequent symptom of disease in this salmonid, but seldom reported of brown trout (Hedrick et al. 1999b) or bull trout (Hedrick 1999b, Vincent 2002). Though we detected lesions throughout cartilage of the cranium in Yellowstone cutthroat comparable to those reported for rainbow trout (Hedrick et al. 1999b, Baldwin et al. 2000, MacConnell \& Vincent 2002), the prevalence of black tail was negligible in Yellowstone cutthroat but usually high in rainbow trout (and brown trout) (Hedrick 1999a, MacConnell \& Vincent 2002, Vincent 2002). This may suggest that infection in vertebral cartilage of Yellowstone cutthroat trout is rare or if vertebrae do get infected lesions are not as significant as in axial skeleton of rainbow trout (Markiw \& Wolf 1974, Bald- 
win et al. 2000, Rose et al. 2000). For example, $50 \%$ of our fry head sections (265 slides) included vertebrae, $99.2 \%$ of which showed no infection in this region. Alternatively, the lack of black tails among Yellowstone cutthroat trout fry may be due to impenetrability of the skin, or peripheral nerve location, in caudal regions in comparison to that of other salmonids (e.g. rainbow trout; El-Matbouli et al. 1995, 1999).

Several investigations describe rainbow trout as the most susceptible salmonid to Myxobolus cerebralis infection (O'Grodnick 1979, Hoffman 1990, Hedrick et al. 1998), but Yellowstone cutthroat trout showed infection severity similar to that reported of rainbow trout when exposed to $M$. cerebralis-infected waters in the field (Hiner \& Moffitt 2001, Vincent 2002). Genetic similarities between the 2 salmonid species may exist but this remains a controversial topic. Recent evidence suggests a lower genetic divergence from rainbow trout by Yellowstone cutthroat trout than by other subspecies of cutthroat (Smith et al. 2002), while others report smaller genetic distances between rainbow trout and Westslope cutthroat or Coastal cutthroat trout Oncorhynchus clarki clarki than between rainbow and Yellowstone cutthroat trout (Allendorf \& Leary 1988, Behnke 1992). We found infection levels similar to, or higher than those reported for Yellowstone cutthroat trout both younger (10-15 d; Hiner \& Moffitt 2001) and older (3 mo; Hedrick et al. 1999a) than ours. Genetic stock differences may, in part, explain such differences in response to infection among Yellowstone cutthroat trout. The genetic makeup of cutthroat trout used in previous investigations (e.g. Hedrick et al. 1999a, Hiner \& Moffitt 2001) was probably different from that of pure Yellowstone cutthroat trout of Yellowstone Lake tributaries. The native cutthroat trout of the Yellowstone Lake basin were isolated from the downstream watershed during deglaciation about 12000 yr BP (Behnke 1992). This isolation combined with the highly stable, nutrient-rich hydrothermal environment of Yellowstone Lake (Kilham et al. 1996) may render the native cutthroat illadapted against recently introduced pathogens.

All our study sites tested positive for Myxobolus cerebralis. Infection severity and development of clinical signs are directly related to parasite spore concentration (Markiw 1992, Ryce et al. 2004), thus our results suggest that $M$. cerebralis abounds in Pelican Creek. If instead, parasite concentrations are low in Pelican Creek our results suggest that Yellowstone cutthroat trout are vulnerable to whirling disease even at low spore doses. Spore concentrations of $M$. cerebralis in this tributary were not measured directly (e.g. Thompson \& Nehring 2000, Lukins 2004), but we found close similarities in infection response between our Yellowstone cutthroat trout and reports of rainbow trout exposed to controlled, high parasite doses (Hedrick et al. 1999a,b, Ryce et al. 2004). The severity of infection we observed in cranial and lower jaw cartilage could significantly reduce the young fry's ability to survive in the wild.

A number of environmental factors may also influence fish-host susceptibility to whirling disease in natural settings (de la Hoz Franco \& Budy 2004, Krueger et al. 2006). In Pelican Creek, the August exposure showed the least prevalence and severity of infection, when mean water temperature was $16^{\circ} \mathrm{C}$. Myxobolus cerebralis infection among rainbow and cutthroat trout was positively correlated to mean water temperature in Montana (Baldwin et al. 2000) and Idaho (Hiner \& Moffitt 2002), but may decline significantly in rainbow trout above a threshold temperature of about $16^{\circ} \mathrm{C}$ (Hedrick et al. 1998). During our August exposure, mean dissolved oxygen and $\mathrm{pH}$ were higher than in the July and September exposures. This possibly reduced environmental stress and thereby the fry's disposition to infection, or increased their ability to cope with infection. Cutthroat trout require waters with high dissolved oxygen content and a slightly basic pH ranging from 6.5 to 8.0 (Hickman \& Raleigh 1982). In contrast, the most prevalent and severe infection generally occurred during the July exposure, when mean water temperature was nearly $20^{\circ} \mathrm{C}$ and dissolved oxygen was low. The stress of warm, widely fluctuating temperatures may have weakened the physiological condition of sentinel fry (e.g. Schaperclaus 1992, Hedrick 1998). Despite mean water temperature being favorable for cutthroat trout during the September exposure, specific conductivity was higher than the July and August exposures. Conductivity was positively correlated with salmonid infection risk (Hiner \& Moffit 2001, 2002, Sandell et al. 2001) and infection was high during our September exposure (especially $90 \mathrm{~d}$ post-exposure).

The native Yellowstone cutthroat trout is currently listed as a species of special concern by state and federal agencies and the Pelican Creek population has already shown a dramatic decline since the mid-1980s (Koel et al. 2005, in press). Establishment of Myxobolus cerebralis in this and other tributaries may contribute to further reductions in the Yellowstone Lake population of native cutthroat trout. It is therefore important that we continue to investigate this system as it offers a great opportunity to study the dynamics of whirling disease in the natural environment.

Acknowledgements. We thank the Whirling Disease Initiative of the National Partnership on Management of Wild and Native Cold Water Fisheries for their partial funding of this work. Also, thanks to the Center for Resources, Yellowstone National Park, the Rocky Mountain Center for Ecosystems 
Studies Unit (National Park Service), and Montana State University for their funding. C. Fraser, E. Ryce, L. Beck, M. Bensley, C. Hudson, S. Pidgeon, C. Rasmussen, and L. Vannest provided technical assistance. The fisheries biologists, technicians, and volunteers of Yellowstone National Park Fisheries and Aquatic Sciences Section assisted with field and laboratory work. T. E. McMahon revised an earlier version of this manuscript.

\section{LITERATURE CITED}

Allendorf FW, Leary RF (1988) Conservation and distribution of genetic variation in a polytypic species, the cutthroat trout. Cons Biol 2:170-184

Andree KB, MacConnell E, Hedrick RP (1998) A nested polymerase chain reaction for the detection of genomic DNA of Myxobolus cerebralis in rainbow trout Oncorhynchus mykiss. Dis Aquat Org 34:145-154

Andree KB, Hedrick RP, MacConnell E (2002) A review of the approaches to detect Myxobolus cerebralis, the cause of salmonid whirling disease. In: Bartholomew JL, Wilson JC (eds) Whirling disease: reviews and current topics. Am Fish Soc Symp 29, Bethesda, MD, p 197-211

Baldwin TJ, Vincent RE, Silflow RM, Stanek D (2000) Myxobolus cerebralis infection in rainbow trout (Oncorhynchus mykiss) and brown trout (Salmo trutta) exposed under natural stream conditions. J Vet Diagn Invest 12: 312-321

Behnke RJ (1992) Native trout of western North America. Am Fish Soc Monogr 6, Bethesda, MD

de la Hoz Franco E, Budy P (2004) Linking environmental heterogeneity to the distribution and prevalence of MyxoboIus cerebralis: a comparison across sites in a northern Utah watershed. Trans Am Fish Soc 133:1176-1189

El-Matbouli M, Fischer-Scherl T, Hoffmann RW (1992) Present knowledge of the life cycle, taxonomy, pathology, and therapy of some Myxosporea species important for freshwater fish. Annu Rev Fish Dis 3:367-402

El-Matbouli M, Hoffmann RW, Mandok C (1995) Light and electron microscopic observations on the route of the triactinomyxon-sporoplasm of Myxobolus cerebralis from epidermis into rainbow trout cartilage. J Fish Biol 46: 919-935

El-Matbouli M, Hoffmann RW, Schoel H, McDowell TS, Hedrick RP (1999) Whirling disease: host-specificity and interaction between the actinosporean stage of Myxobolus cerebralis and rainbow trout Oncorhynchus mykiss. Dis Aquat Org 35:1-12

Gotelli NJ, Ellison AM (2004) A primer of ecological statistics. Sinauer Associates, Sunderland, MA

Halliday MM (1976) The biology of Myxosoma cerebralis: the causative organism of whirling disease. J Fish Biol 9: 339-357

Hedrick RP (1998) Relationships of the host, pathogen, and environment: implications for diseases of cultured and wild fish populations. J Aquat Anim Health 10:107-111

Hedrick RP, El-Matbouli M, Adkison MA, MacConnell E (1998) Whirling disease: re-emergence among wild trout. Immunol Rev 166:365-376

Hedrick RP, McDowell TS, Mukkatira K, Georgiadis MP, MacConnell E (1999a) Susceptibility of selected inland salmonids to experimentally induced infections with Myxobolus cerebralis, the causative agent of whirling disease. J Aquat Anim Health 11:330-339

Hedrick RP, McDowell TS, Gay M, Marty GD, Georgiadis MP, MacConnell E (1999b) Comparative susceptibility of rain- bow trout Oncorhynchus mykiss and brown trout Salmo trutta to Myxobolus cerebralis, the cause of salmonid whirling disease. Dis Aquat Org 37:173-183

Hickman T, Raleigh RF (1982) Habitat suitability index models: cutthroat trout. US Department of the Interior, Fish and Wildlife Service Report FWS/OBS-82/10.5. US Government Printing Office, Washington DC

Hiner M, Moffitt CM (2001) Variation in infection of Myxobolus cerebralis in field-exposed cutthroat trout in Idaho. J Aquat Anim Health 13:124-132

Hiner M, Moffitt CM (2002) Modeling Myxobolus cerebralis in trout: associations with habitat variables. In: Bartholomew JL, Wilson JC (eds) whirling disease: reviews and current topics. Am Fish Soc Symp 29, Bethesda, MD, p 167-179

Hoffman GL (1990) Myxobolus cerebralis, a worldwide cause of salmonid whirling disease. J Aquat Anim Health 2:30-37

Humason GL (1979) Animal tissue techniques. WH Freeman, San Francisco, CA

Kerans BL, Dybdahl MF, Gangloff MM, Jannot JE (2005) Potamopyrgus antipodarum: distribution, density, and effects on native macroinvertebrate assemblages in the Greater Yellowstone ecosystem. J North Am Benthol Soc 24:123-138

Kilham SS, Theriot EC, Fritz SC (1996) Linking planktonic diatoms and climate change in the large lakes of the Yellowstone ecosystem using resource theory. Limnol Oceanogr 41:1052-1062

Koel TM, Bigelow PE, Doepke PD, Ertel BD, Mahony DL (2005) Nonnative lake trout result in Yellowstone cutthroat trout decline and impacts to bears and anglers. Fisheries 30:10-19

Koel TM, Mahony DL, Kinnan KL, Rasmussen C, Hudson CJ, Murcia S, Kerans BL (in press) Myxobolus cerebralis in native cutthroat trout of the Yellowstone ecosystem. $\mathrm{J}$ Aquat Anim Health

Krueger RC, Kerans BL, Rasmussen C, Vincent ER (2006) Correlations among environmental features, Myxobolus cerebralis infection prevalence in oligochaetes, and salmonid infection risk in the Madison River, Montana. Ecol Appl $16: 770-783$

Lukins HJ (2004) Dynamics of the waterborne stage of Myxobolus cerebralis estimated directly by packed-bed filtration. MS Thesis, Montana State University, Bozeman, MT

MacConnell E, Vincent RE (2002) The effects of Myxobolus cerebralis on the salmonid host. In: Bartholomew JL, Wilson JC (eds) Whirling disease: reviews and current topics. Am Fish Soc Symp 29, Bethesda, MD, p 95-107

Markiw ME (1992) Experimentally induced whirling disease I. Dose response of fry and adults of rainbow trout exposed to the triactinomyxon stage of Myxobolus cerebralis. J Aquat Anim Health 4:40-43

Markiw ME, Wolf K (1974) Myxosoma cerebralis: comparative sensitivity of spore detection methods. J Fish Res Board Can 31:1597-1600

O'Grodnick JJ (1979) Susceptibility of various salmonids to whirling disease (Myxosoma cerebralis). Trans Am Fish Soc 108:187-190

Parks R (1998) Fishing Yellowstone National Park. Falcon Publishing, Helena, MT

Rose JD, Marrs GS, Lewis C, Schisler G (2000) Whirling disease behavior and its relation to pathology of brain stem and spinal cord in rainbow trout. J Aquat Anim Health 12: $107-118$

Ruzycki JR, Beauchamp DA, Yule DL (2003) Effects of introduced lake trout on native cutthroat trout in Yellowstone Lake. Ecol Appl 13:23-37 
Ryce EKN, Zale AV, MacConnell E (2004) Effects of fish age and parasite dose on the development of whirling disease in rainbow trout. Dis Aquat Org 59:225-233

Ryce EKN, Zale AV, MacConnell E, Nelson M (2005) Effects of fish age versus size on the development of whirling disease in rainbow trout. Dis Aquat Org 63:69-76

Sandell TA, Lorz HV, Stevens DG, Bartholomew JL (2001) Dynamics of Myxobolus cerebralis in the Lostine River, Oregon: implications for resident and anadromous salmonids. J Aquat Anim Health 13:142-150

Schaperclaus W (1992) Causes, development and prevention of fish diseases. In: Schaperclaus W, Kulow H, Schreckenback K (eds) Fish diseases, 5th edn. AA Balkema Publisher, Rotterdam

Smith GR, Dowling TE, Gobalet KW, Lugaski TSDK, Evans RP (2002) Biogeography and timing of evolutionary events among Great Basin fishes. In: Hershler R, Madsen DB, Currey DR (eds) Great Basin Aquatic, Systems History.

Editorial responsibility: Wolfgang Körting,

Hannover, Germany
Smithson Contrib Earth Sci. Smithsonian Institute, Washington DC

Thompson KG, Nehring RB (2000) A simple technique used to filter and quantify the actinospores of Myxobolus cerebralis and determine its seasonal abundance in the Colorado River. J Aquat Anim Health 12:316-323

Thompson KG, Nehring RB, Bowden DC, Wygant T (1999) Field exposure of seven species or subspecies of salmonids to Myxobolus cerebralis in the Colorado River, Middle Park, Colorado. J Aquat Anim Health 11:312-329

Vincent ER (2002) Relative susceptibility of various salmonids to whirling disease with an emphasis on rainbow and cutthroat trout. In: Bartholomew JL, Wilson JC (eds) Whirling disease: reviews and current topics. Am Fish Soc Symp 29, Bethesda, MD, p 109-115

Wagner E, Arndt R, Brough M, Roberts DW (2002) Comparison of susceptibility of five cutthroat trout strains to Myxobolus cerebralis infection. J Aquat Anim Health 14:84-91

Submitted: June 28, 2005; Accepted: July 4, 2006

Proofs received from author(s): August 2, 2006 